\title{
Dry Sliding Wear Behavior of Aluminum 6063 Composites Reinforced with $\mathrm{TiB}_{2}$ Particles
}

\author{
K. Krishnamurthy ${ }^{1 *}$, Mengistu Ashebre1, J. Venkatesh ${ }^{2}$, B. Suresha ${ }^{3}$ \\ ${ }^{1}$ School of Mechanical \& Industrial Engineering, Ethiopian Institute of Technology-Mekelle, Mekelle University, Mekelle, \\ Ethiopia \\ ${ }^{2}$ Department of Automobile Engineering, People's Education Society College of Engineering, Mandya, India \\ ${ }^{3}$ Department of Mechanical Engineering, The National Institute of Engineering, Mysore, India \\ Email: kkm.aitmech@gmail.com
}

How to cite this paper: Krishnamurthy, K., Ashebre M., Venkatesh, J. and Suresha, B. (2017) Dry Sliding Wear Behavior of Aluminum 6063 Composites Reinforced with TiB2 Particles. Journal of Minerals and Materials Characterization and Engineering, 5, 74-89. https://doi.org/10.4236/jmmce.2017.52007

Received: April 18, 2016

Accepted: March 28, 2017

Published: March 31, 2017

Copyright $\odot 2017$ by authors and Scientific Research Publishing Inc. This work is licensed under the Creative Commons Attribution International License (CC BY 4.0).

http://creativecommons.org/licenses/by/4.0/

cC) (i) Open Access

\begin{abstract}
The influence of titanium diboride $\left(\mathrm{TiB}_{2}\right)$ loading on the dry sliding wear characteristics of aluminum 6063 matrix alloy-titanium diboride $\left(\mathrm{Al} / \mathrm{TiB}_{2}\right)$ composite materials has been assessed using a pin-on disc wear tester at different loads. The composites with 5 and $10 \mathrm{wt} \%$ of fine $\mathrm{TiB}_{2}$ particles were fabricated using stir casting technique. For comparison, as-cast of the base alloy were made under the same processing applied for $\mathrm{Al} / \mathrm{TiB}_{2}$ composites. The hardness of the composite materials was measured using Brinell hardness tester. Scanning electron microscopy (SEM) was used to analyze the wear surfaces of samples. The results indicate that fine $\mathrm{TiB}_{2}$ particles markedly improved the wear performance of the aluminum 6063 matrix alloy. The coefficient of friction decreases with increase in the amount of $\mathrm{TiB}_{2}$, but this effect was more pronounced in dry sliding. Hardness of composites increased with increasing $\mathrm{TiB}_{2}$ loading. The wear rates increase with increase in load and dependent upon $\mathrm{TiB}_{2}$ loading in the base alloy. Among the composites tested, $\mathrm{Al} / \mathrm{TiB}_{2}$ composites containing $10 \mathrm{wt} \% \mathrm{TiB}_{2}$ exhibited superior wear resistance over the base alloy and $5 \mathrm{wt} \% \mathrm{Al} / \mathrm{TiB}_{2}$ composites. These observations were correlated in terms of the $\mathrm{TiB}_{2}$ loading in base alloy which resulted in the variations of the hardness.
\end{abstract}

\section{Keywords}

$\mathrm{TiB}_{2}$ Reinforced Aluminum 6063, Hardness, Sliding Wear, Wear Rate, Wear Resistance

\section{Introduction}

Owing to the high strength-to-weight ratio, aluminium has been found wide application in areas where light weight is of primary considerations. Aluminium 
based particulate-reinforced metal matrix composites are well known for their higher specific modulus and strength as well as for their excellent wear resistance when compared to their monolithic counterparts [1]. Metal matrix composites have emerged as an important class of high performance material for use in aerospace, automobile, chemical and transportation industries because of their improved strength, high elastic modulus and increased wear resistance over conventional base alloys. Aluminium based composites $\mathrm{SiC}, \mathrm{B}_{4} \mathrm{C}, \mathrm{Al}_{2} \mathrm{O}_{3}$, $\mathrm{TiC}$ [2] and graphite reinforce aluminium or its alloys have been the interest of research. Among these reinforcements, $\mathrm{TiB}_{2}$ has emerged as a promising candidate for $\mathrm{Al}$ base composites; this is due to fact that the $\mathrm{TiB}_{2}$ is stiff, hard and does not react to form the reaction products at the reinforcement interfaces [3] [4] [5]. $\mathrm{TiB}_{2}$ is a refractory compound that exhibits outstanding features such as high melting point $\left(2790^{\circ} \mathrm{C}\right)$, high hardness ( $86 \mathrm{HRA}$ or $960 \mathrm{HV}$ ) and high modulus characteristics. Its resistance to plastic deformation even at high temperatures portrays it to be a good potential reinforcing candidate in an aluminum matrix. 5 and 10 wt. $\% \mathrm{TiB}_{2}$ particles reinforced aluminum (A16063) metal matrix composites produced by using master alloys of Al-Ti \& B by stir casting process to obtain the material for the experiment [6] [7] [8] [9]. Limited published work is only available on the sliding wear behavior of composites with $\mathrm{TiB}_{2}$ as reinforcement material [10] [11] [12]. Mandal et al. [10] in their study of sliding wear of composites stated that $\mathrm{TiB}_{2}$ particles markedly improved the wear performance of $\mathrm{Al}-4 \mathrm{Cu}$ alloy. Lee et al. [11] showed that increased volume fraction of $\mathrm{TiB}_{2}$ in the composite has not led to a parallel increase in wear resistance. This behavior is attributed to the presence of the unavoidable $\mathrm{Al}_{3} \mathrm{Ti}$ phase in the Al-Ti-B system. Zhao Min et al. [12] showed $\mathrm{TiB}_{2} / \mathrm{Al}$ composites exhibit higher wear resistance than $\mathrm{SiCp} / \mathrm{Al}$ composite. Severe plastic deformation and adhesive wear were found on the worn surfaces of $\mathrm{SiCp} / \mathrm{Al}$ composite, but no such worn surfaces observed in the $\mathrm{TiB}_{2} / \mathrm{Al}$ composites. Roy et al. [13] have compared wear resistance of aluminium reinforced with $\mathrm{TiC}, \mathrm{TiB}_{2}, \mathrm{~B} 4 \mathrm{C}, \mathrm{SiC}$. It was stated that $\mathrm{TiB}_{2}$ showed better wear resistance than the other dispersiods.

Kumar et al. [14] [15] noted that abrasive wear resistance improved by the addition of $\mathrm{TiB}_{2}$ particle in the $\mathrm{Al}-4 \mathrm{Cu}$ alloy and it increases as the $\mathrm{TiB}_{2}$ content in the composites increases. Ramesh et al. [16] observed that a decrease in wear rate with increase in the $\mathrm{TiB}_{2}$ content in the composites. Maximum reduction is in the wear rate for the composites containing $10 \mathrm{wt} \% \mathrm{TiB}_{2}$ when compared with matrix alloy. Sivaprasad et al. [17] noted that as $\mathrm{wt} \%$ of $\mathrm{TiB}_{2}$ particles increases, volume loss decreases, and with increase in distance traversed, volume loss increases.

Natarajan et al. [18] showed that the dry sliding at room temperature increases the wear resistance of Al-6063 alloy by the reinforcement of $\mathrm{TiB}_{2}$ particles. Basavarajappa et al. [19] showed that wear rate decreases as the sliding speed increases when $\mathrm{SiC}$ particles reinforced into Al-2219 alloy, up to transition speed and load, due to work hardening of surface, formation of Iron oxide and crushing the $\mathrm{SiC}$ particles. The present study was attempted to study the dry sliding 
wear behavior of Al-6063 alloy reinforced with $\mathrm{TiB}_{2}$ particles at different loads, sliding velocity and different $w t \%$ reinforcement. The worn surfaces are studied using SEM photographs.

\section{Experimental Details}

\subsection{Materials}

Aluminium 6063 alloy was selected as the base line material as it possesses good formability, weldability, machinability and corrosion resistance, with medium strength compared to other grades of aluminium alloys. Its nominal chemical composition is shown in Table 1 . The commercially available Al-6063 matrix alloy and master alloy are melted in an electric resistance furnace. The percentage weight of Al-Ti \& B \% was varied from 0 - $10 \mathrm{wt} \%$ in steps of $5 \mathrm{wt} \%$. The mixture of matrix alloy and master alloy were melted in an electric resistance furnace at a temperature of $800^{\circ} \mathrm{C}$ and allowed to stand for duration of about 30 min to get melts. The melt was degassed using commercially available chlorine based tablets (Hexa-chloroethane) to remove the entrapped gases before stirring the melt using stirrer to get in-situ composites of $\mathrm{TiB}_{2}$ in $\mathrm{Al} 6063$ alloy. The melt is poured into the preheated metallic moulds. The different $\%$ composition $(0,5$ and 10) of Al-6063- $\mathrm{TiB}_{2}$ composites rods are prepared of size $\varnothing 22 \mathrm{~mm} \times 120$ $\mathrm{mm}$.

\subsection{Microscopy, Density and Hardness Measurements}

In order to know the dispersion of $\mathrm{TiB}_{2}$ in $\mathrm{Al6063}$, the samples for microscopic examinations were prepared based on the standard metallographic procedures, etched with Keller's agent and were analyzed by scanning electron microscope (SEM).The density of the composites was obtained by the Archimedes's principle of weighing small pieces cut from the composite disc first in air and then in water. Then, theoretical density of composite and its alloy was calculated from the chemical analysis data. The porosity of the composites was also determined. The hardness of the composites and matrix alloy were measured after polishing to a $3 \mathrm{~mm}$ finish. The magnification of the images was $500 \times$. Hardness of all samples was measured by Brinell hardness tester and mean of at least five readings was taken to represent the sample.

\subsection{Dry Sliding Wear Test}

A pin-on-disc machine shown in Figure 1 was used to investigate the dry sliding wear behavior of the aluminium alloy and $\mathrm{TiB}_{2} / \mathrm{Al}-6063$ composites as per ASTM G99. Specimen of $\varnothing 8 \mathrm{~mm} \times 28 \mathrm{~mm}$ in length were cut out of rods of size $\varnothing 22 \mathrm{~mm} \times 120 \mathrm{~mm}$, by the specimen cutter, machined, and then polished me-

Table 1. Chemical composition of Al-6063 alloy.

\begin{tabular}{cccccccccc}
\hline Element & $\mathrm{Mg}$ & $\mathrm{Si}$ & $\mathrm{Fe}$ & $\mathrm{Cu}$ & $\mathrm{Mn}$ & $\mathrm{Zn}$ & $\mathrm{Ti}$ & $\mathrm{Cr}$ & $\mathrm{Al}$ \\
\hline wt.\% & $0.45-0.9$ & $0.2-0.6$ & 0.35 & 0.1 & 0.1 & 0.1 & 0.1 & 0.1 & Balance \\
\hline
\end{tabular}




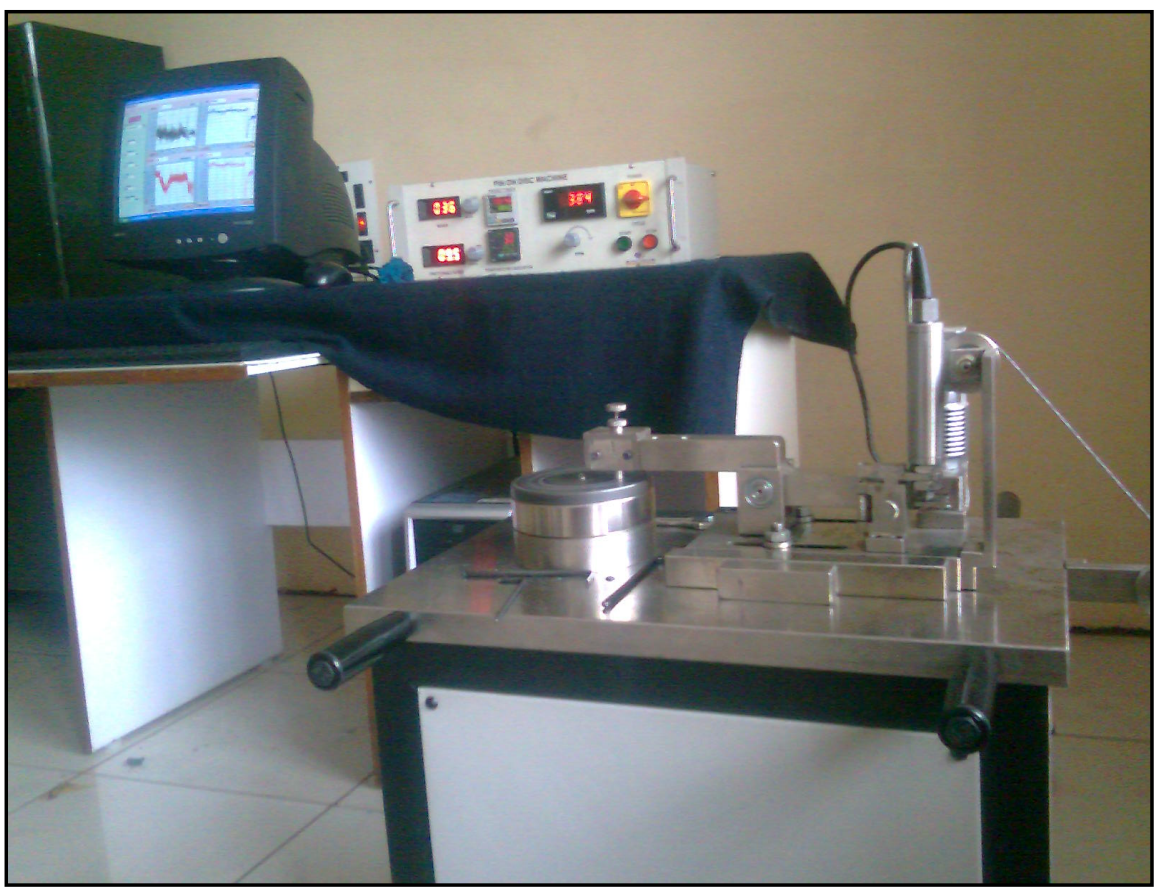

Figure 1. Pin on disc wear testing machine.

tallographically in order to ensure very smooth surface.. Wear tests were conducted with loads ranging from $10-30 \mathrm{~N}$, sliding speed of $500-1500 \mathrm{~m}$ and sliding velocity of $0.5-1.5 \mathrm{~m} / \mathrm{s}$ at room temperature. All tests are conducted at $80 \mathrm{~mm}$ track diameter on the EN24 steel hardened disc with HRC60 by applying normal load. The surface finish of the counterface is $2 \mu \mathrm{m}$. All tests were conducted at room temperature. The duration of time for the test is calculated from the given sliding speed and sliding velocity. The weight loss is calculated considering the weight before and after the wear and the volume loss is determined.

\section{Results and Discussion}

\subsection{Microstructure of $\mathrm{TiB}_{2}$-Al Composites}

The properties of the metal matrix composites (MMCs) depend not only on the matrix, particle, and the volume fraction, but also on distribution of reinforcing particles and interface bonding between the particle and matrix. In practical way, to achieve a homogenous distribution is difficult. The photomicrographs of the aluminum composite reinforced with 5 and $10 \mathrm{wt} \%$ of $\mathrm{TiB}_{2}$ are shown in Figure 2(a) and Figure 2(b) respectively. The particles, with the average particle size of $25 \mu \mathrm{m}$, mainly formed in the surface showed a character of homogenous distribution within the matrix alloy.

\subsection{Density and Hardness of $\mathrm{TiB}_{2}$-Al Composites}

The variations of density and hardness of the composites are shown in Figure 3. The density and hardness of the MMCs increased more or less linearly with the weight fraction of particles in the alloy matrix due to the increasing ceramic phase of the matrix alloy. A significant increase in both density and hardness 


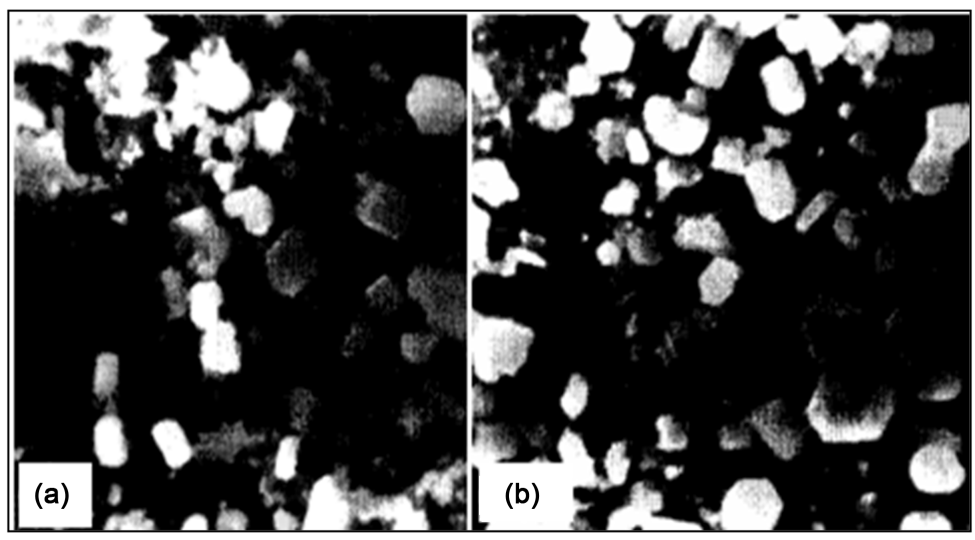

Figure 2. Photomicrographs of $\mathrm{Al} 6063$ composites: (a) 5 and (b) 10 wt. $\% \mathrm{TiB}_{2}$.

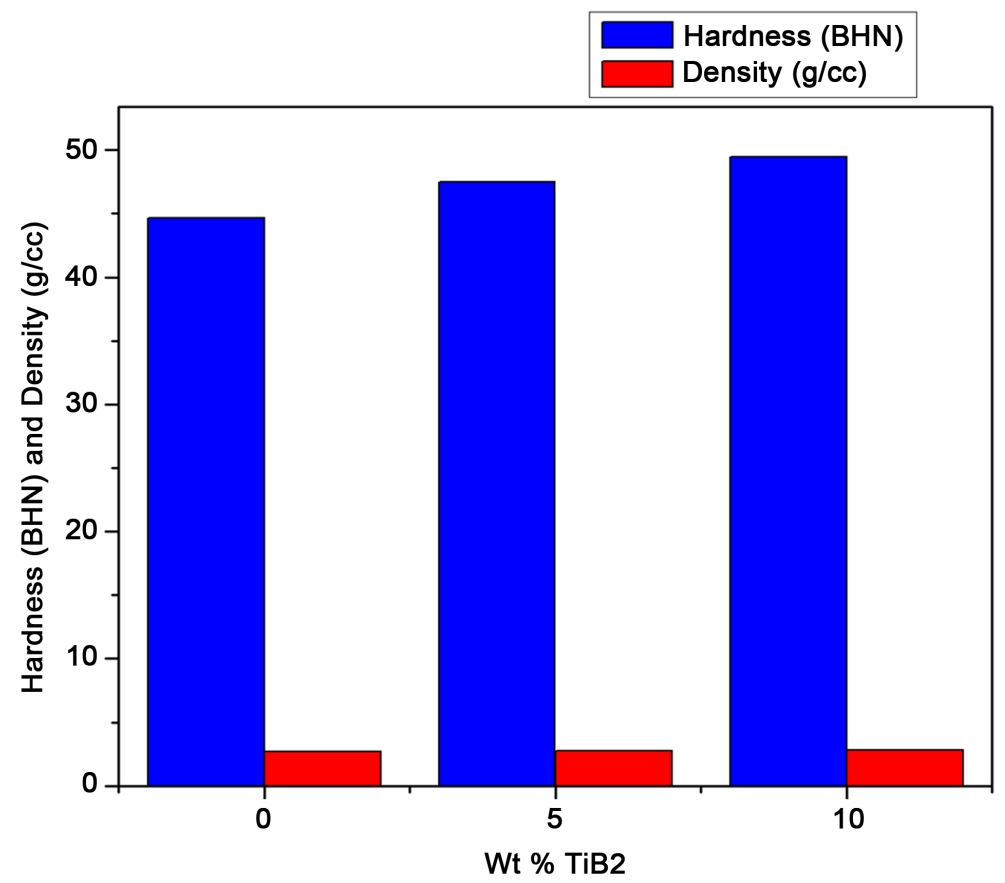

Figure 3. Density and hardness of $\mathrm{TiB}_{2} / \mathrm{Al} 6063$ composites.

was found in $10 \mathrm{wt} \% \mathrm{TiB}_{2}$ into aluminum composite. The increase in density indicates that particle breakage may not have any significant influence on the composites. It is believed to achieve an improvement of the bonding between the particle and matrix. The porosities of composites were evaluated from the difference between the expected and the observed density of each sample. The variations of porosity level in these composites are $1.3 \%$ and $1.5 \%$ for 5 and $10 \mathrm{wt} \%$ $\mathrm{TiB}_{2}$ in aluminum composites respectively. The porosity level increased, since the contact surface area was increased.

\subsection{Wear Rate}

Dry sliding wear tests were conducted to assess the wear behavior of the $\mathrm{TiB}_{2}$ reinforced with Al-6063 composite materials. The experiments were conducted using pin on disc wear testing machine by adopting 81 regular experiments for 
the 3 types of material containing 0, 5 and $10 \mathrm{wt} \% \mathrm{TiB}_{2}$ reinforced with $\mathrm{Al}-6063$ composite materials.

The wear rate of the matrix alloy and the composites are shown as a function of load and wt\% of $\mathrm{TiB}_{2}$ in Figure 4(a) and Figure 4(b) respectively, it shows that for a constant sliding speed and constant load, the wear rate decreases as a function of $\mathrm{TiB}_{2}$ reinforcement in the composites. The Figure 4(a) also shows that, the wear rate increases as the load increases for a particular composite. From the Figure $4(\mathrm{~b})$, the addition of $10 \mathrm{wt} \% \mathrm{TiB}_{2}$ to the matrix alloy decreases the wear rate for all type of loads. High hardness and the good bonding, lower the wear rates in the composites with high $\mathrm{TiB}_{2}$ content [11].

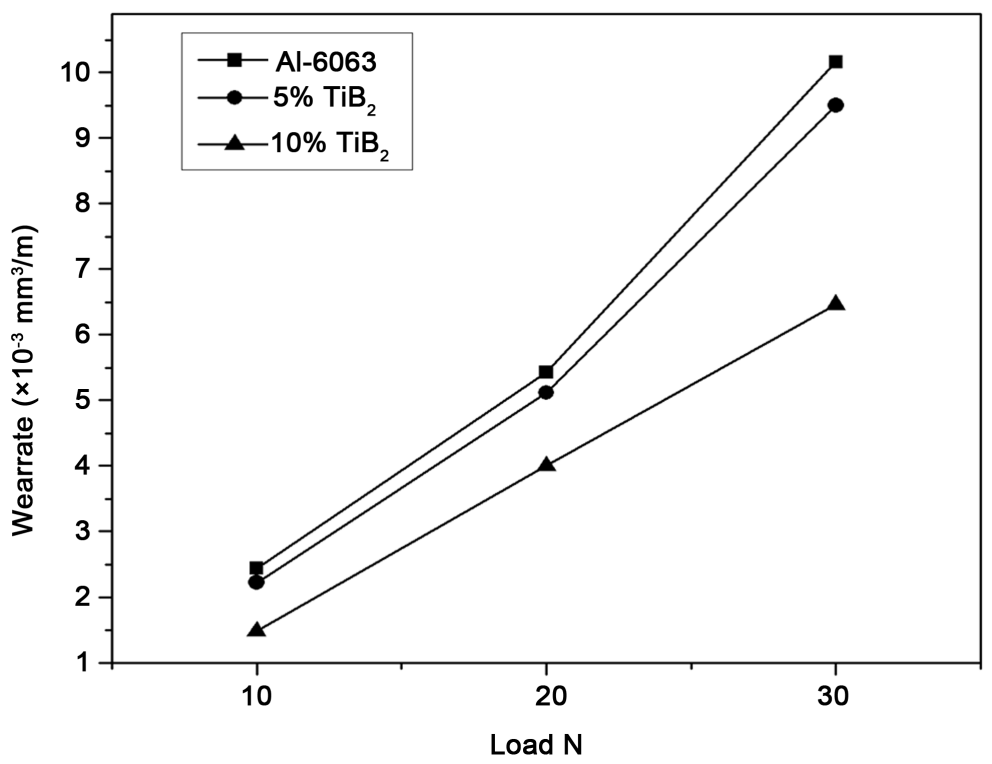

(a)

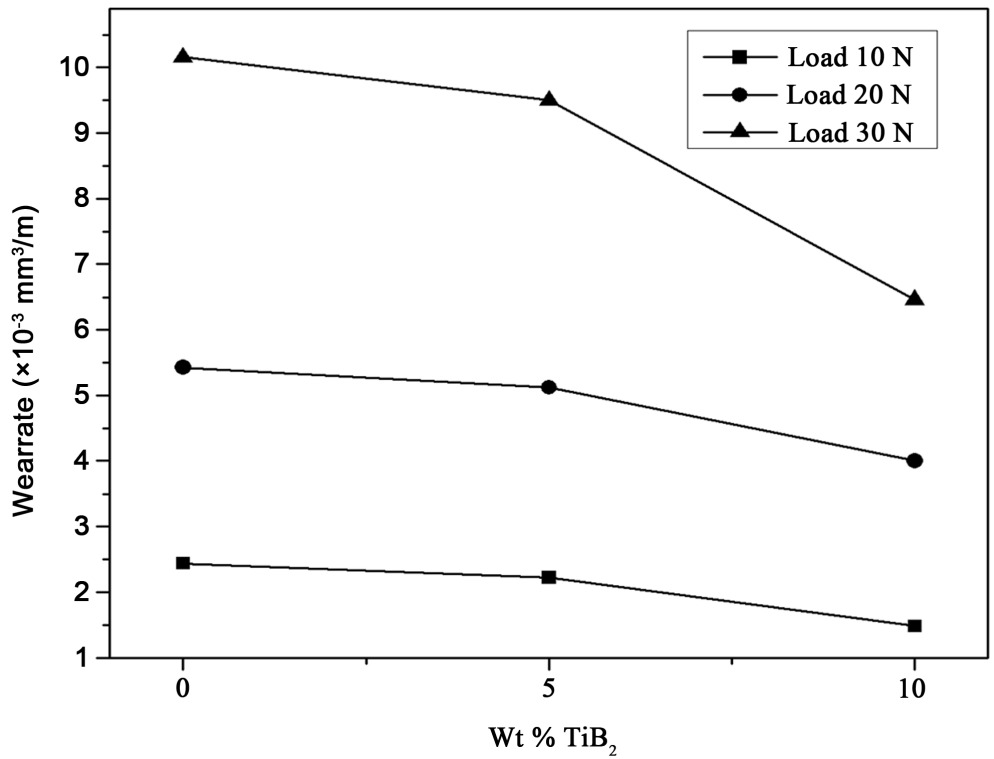

(b)

Figure 4. (a) Variation of wear rate with load for $\mathrm{TiB}_{2} / \mathrm{Al}-6063$ composites; (b) Variation of wear rate with content of $\mathrm{TiB}_{2}$ reinforcement in Al-6063 matrix alloy. 


\subsection{Specific Wear Rate}

The specific wear rate of the matrix alloy and the composites are shown as a function of load and wt. \% of $\mathrm{TiB}_{2}$ in Figure 5(a) and Figure 5(b) respectively, defined as the volume of material worn per unit load. Figure 5(a) shows that the specific wear rate increases drastically at higher loads. Figure 5(b) shows specific wear rate decreases as the increase in wt. $\% \mathrm{TiB}_{2}$ particles in the composites and it decreases as the load increases due to work hardening. This significant improvement in the wear resistance of the $\mathrm{TiB}_{2} / \mathrm{Al}-6063$ composites can be attributed to the following factor:

1) The increase in the hardness of the Al 6063 with increase in the loading of $\mathrm{TiB}_{2}$ reinforcement. The wear rate decreases with increase in hardness. Various researchers reported that the severity of adhesive wear greatly depends on the material hardness. Further, there is an experimental support and practical evidence to suggest that the onset of adhesive process, such as scuffing and seizure are reduced by increasing the hardness of the parts in contact.

2) Also, the excellent bonding between reinforcement and matrix as evidenced by SEM picture shown in Figure 2 .

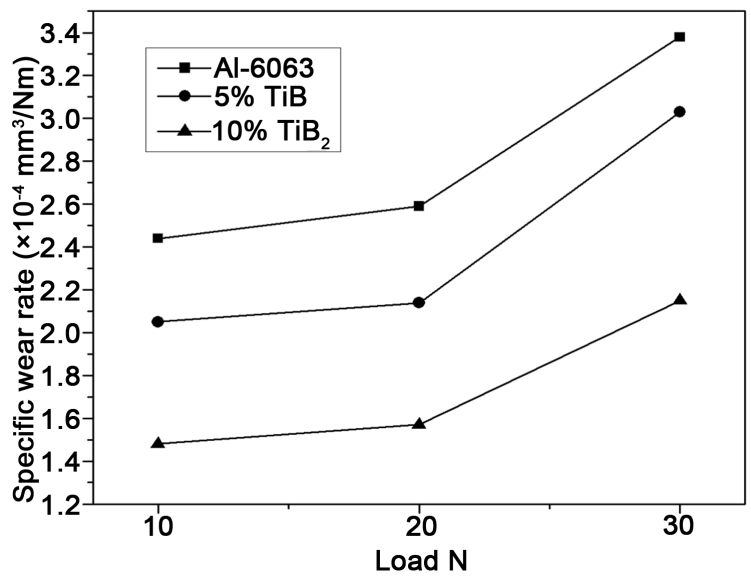

(a)

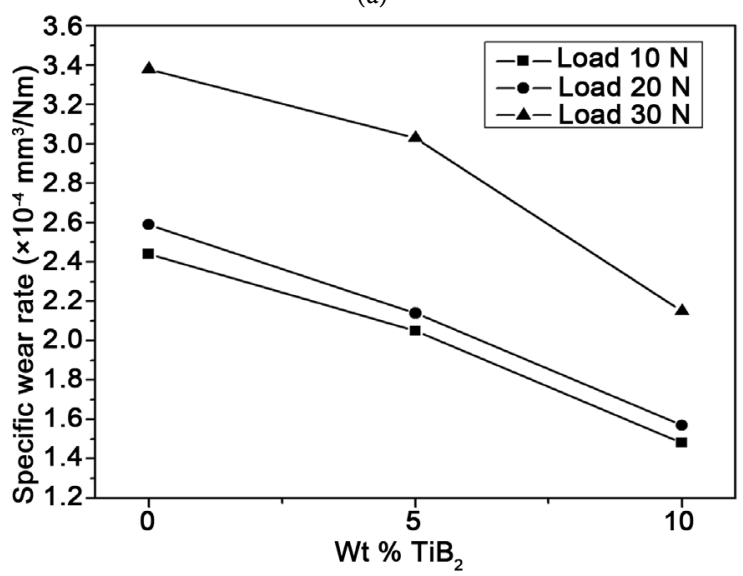

(b)

Figure 5. (a) Variation of specific wear rate with load $\mathrm{TiB}_{2} / \mathrm{Al}-6063$ composites; (b) Variation of specific wear rate with content of $\mathrm{TiB}_{2}$ reinforcement in Al-6063 matrix alloy. 


\subsection{Wear Resistance}

Figure 6(a) and Figure 6(b) shows the wear resistance, defined as the reciprocal of the wear rate, of the composites as a function of normal load and $\mathrm{TiB}_{2}$ reinforcement, respectively. Figure 6(a) shows that the wear resistance decreases as the normal load increases and Figure 6(b) shows it increases as the wt $\% \mathrm{TiB}_{2}$ reinforcement in the composite increases.

\subsection{Worn Surface Morphology}

Dry sliding wear involves the transfer of material from one surface to another during relative motion due to a process of solid state welding, or wear due to localized bonding between contacting solid surfaces. Such type of wear leads to material transfer between two surfaces or loss from either surface. Thus, the SEM analysis of worn surfaces formed during the dry sliding wear in the steady state regime provides an important tool disseminate the wear behavior of the composites more accurately.

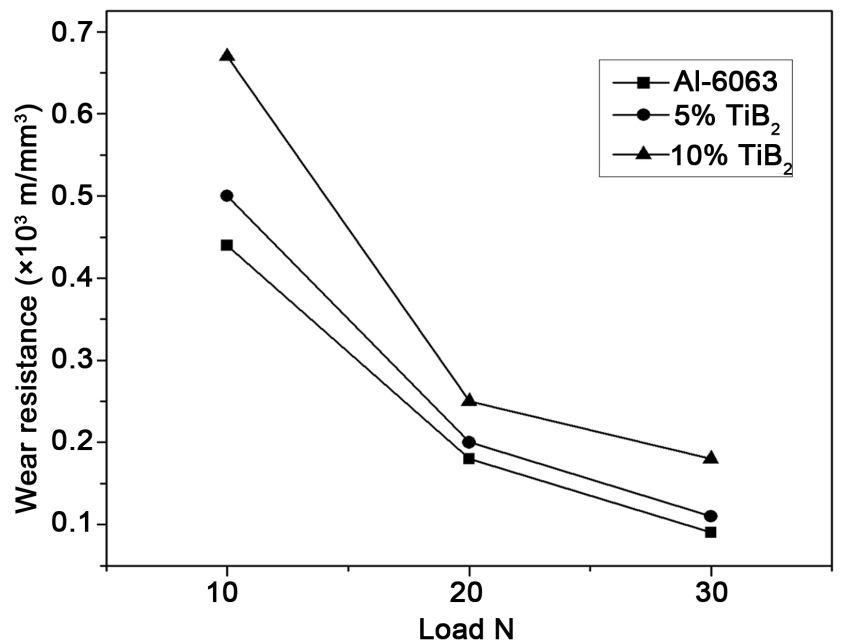

(a)

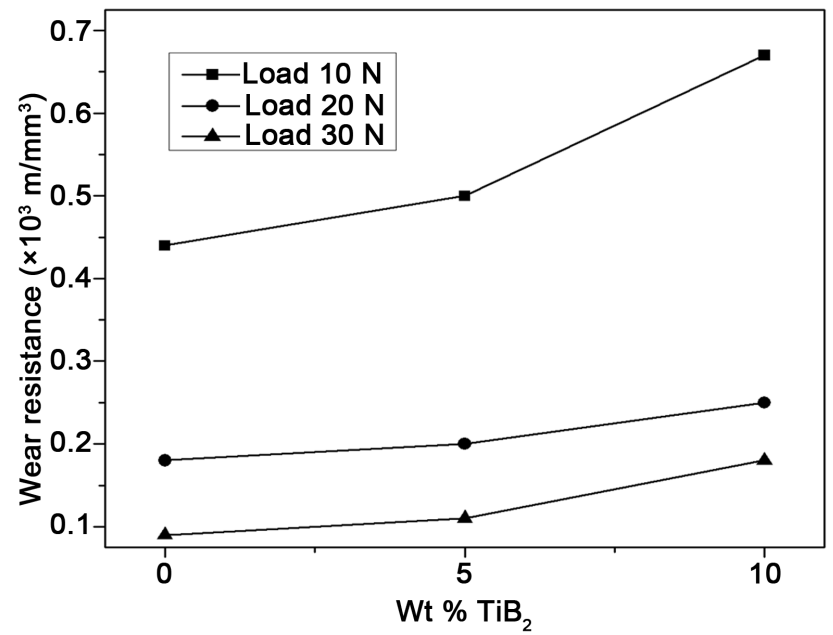

(b)

Figure 6. (a) Variation of wear resistance with load $\mathrm{TiB}_{2} / \mathrm{Al}-6063$ composites; (b) Variation of wear resistance with content of $\mathrm{TiB}_{2}$ reinforcement in Al-6063 matrix alloy. 
Figures 7(a)-(c) shows the microstructure of the $\mathrm{TiB}_{2}$ reinforced Al-6063 alloy. From the figures, it is evident that $\mathrm{TiB}_{2}$ particles are more or less disparesed uniformly in the Al-6063 matrix. The size of the $\mathrm{TiB}_{2}$ particles ranges from 15 to $35 \mu \mathrm{m}$. It also seen from the figures that the $\mathrm{TiB}_{2}$ reinforced Al-6063 composites are free from porosity and shrinkage cavity.
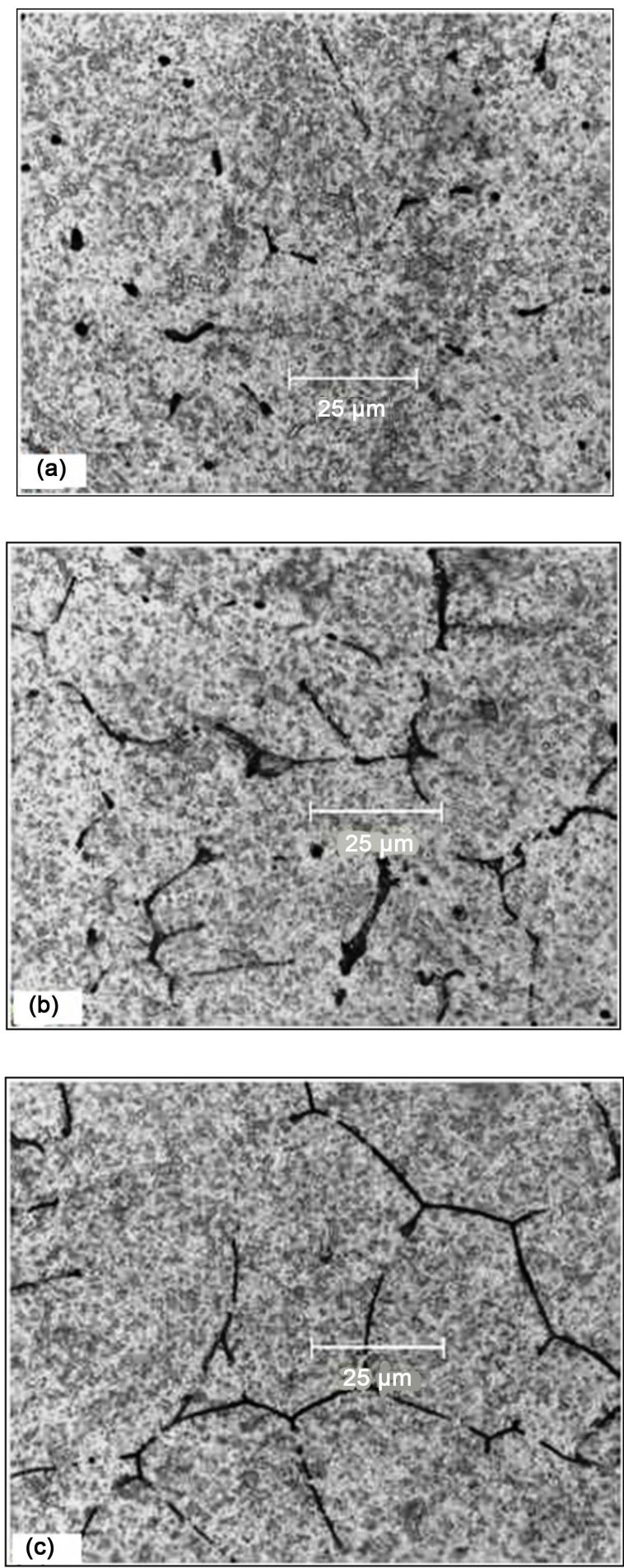

Figure 7. Microstructures of (a) Al-6063 alloy; (b) Al-6063/5\% $\mathrm{TiB}_{2}$ and (c) Al-6063/10\% $\mathrm{TiB}_{2}$. 
For systematic analysis of the worn surfaces of neat alloy and its composites, selected photomicrographs at two different (low and high) loads and sliding velocities were examined using scanning electron microscopy. However, the same explanation holds good even for the other composites and its alloy with different sliding velocity and load.

The examination of the wear surfaces of the matrix alloy and composites reveal distinct pattern of grooves and ridges running parallel to the sliding direction as shown in Figures 8-13. The large amount of plastic deformation was observed on the surface of the neat alloy as shown in Figure 8. The degree of deformation is more pronounced as the load increases from 10 to $30 \mathrm{~N}$ at $0.5 \mathrm{~m} / \mathrm{s}$

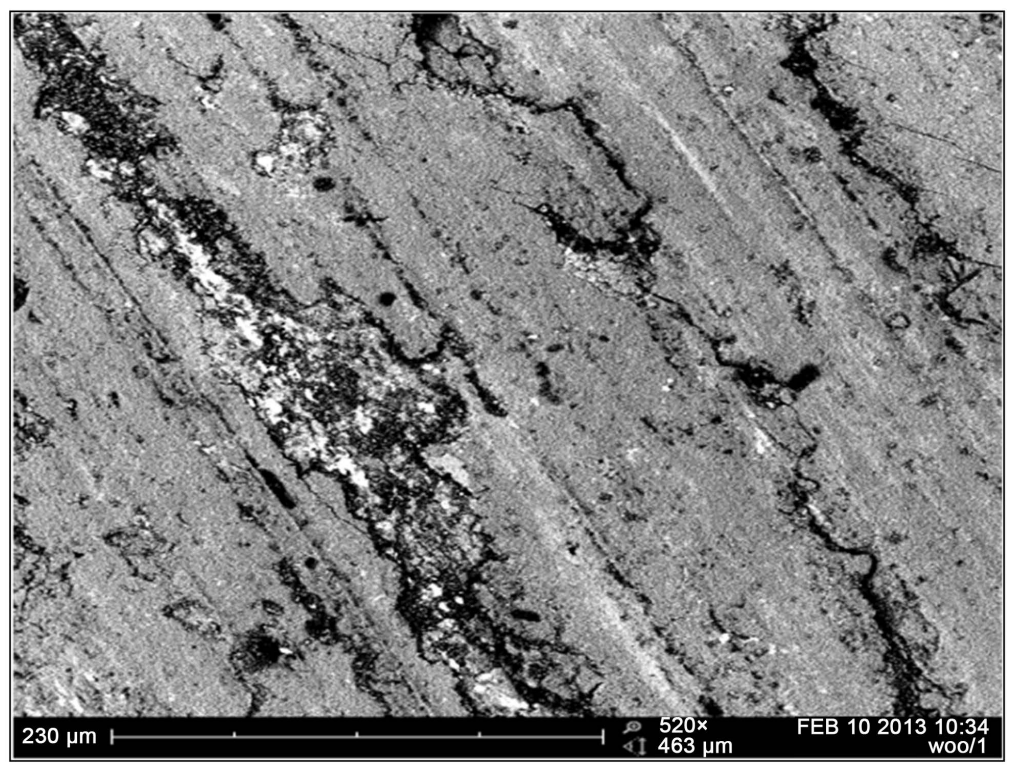

(a)

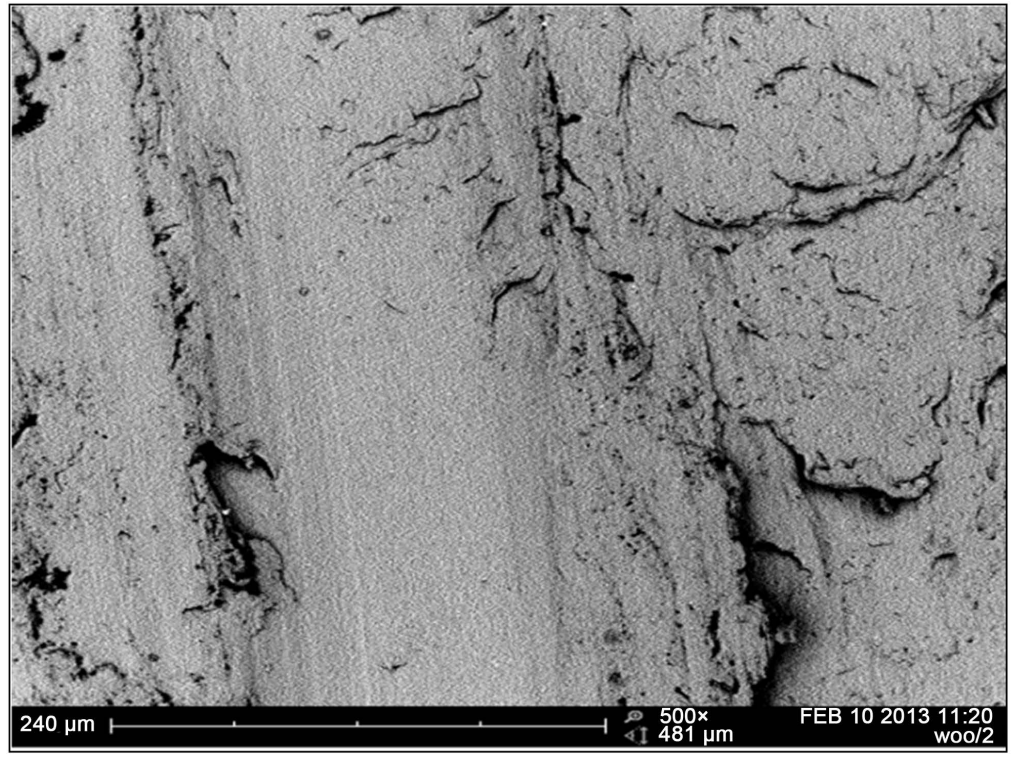

(b)

Figure 8. SEM photomicrographs of worn surfaces of Al-6063 alloy at $0.5 \mathrm{~m} / \mathrm{s}$ (a) 10 and (b) $30 \mathrm{~N}$. 


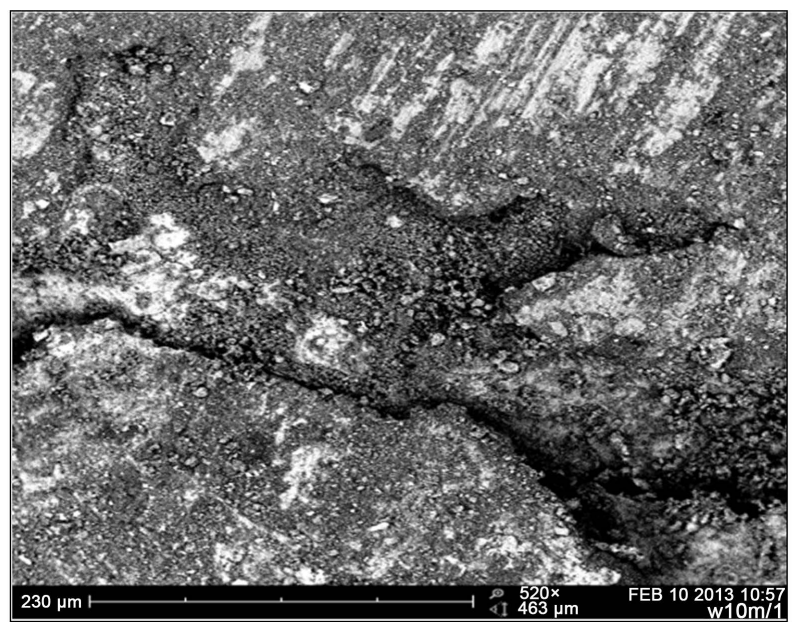

(a)

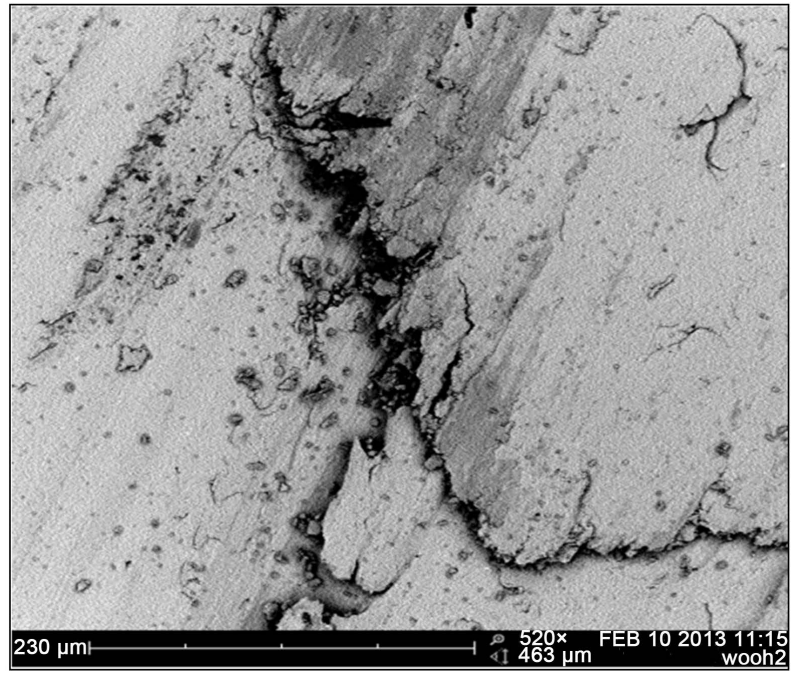

(b)

Figure 9. SEM photomicrographs of worn surfaces of Al-6063 alloy at $1.5 \mathrm{~m} / \mathrm{s}$ (a) 10 and (b) $30 \mathrm{~N}$.

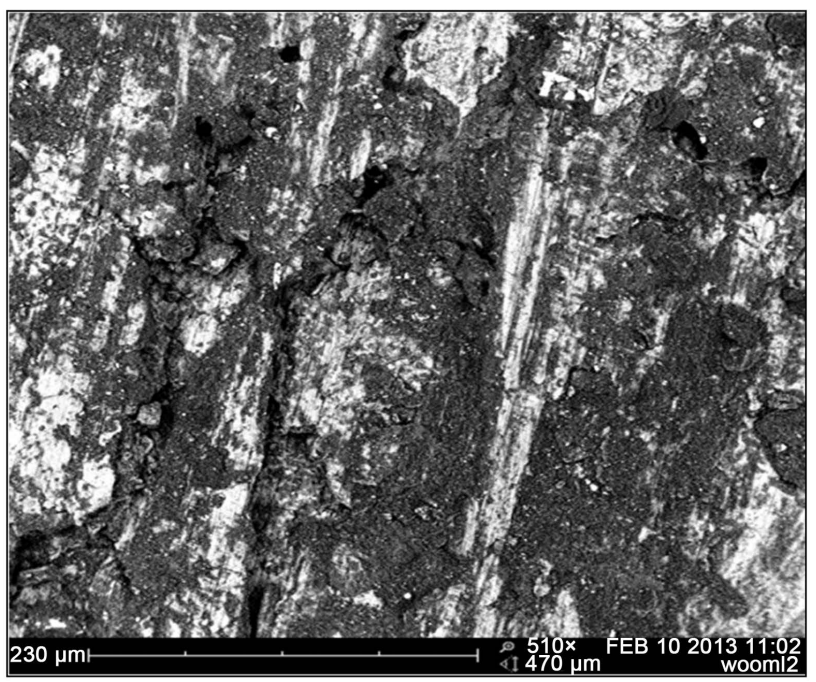

(a) 


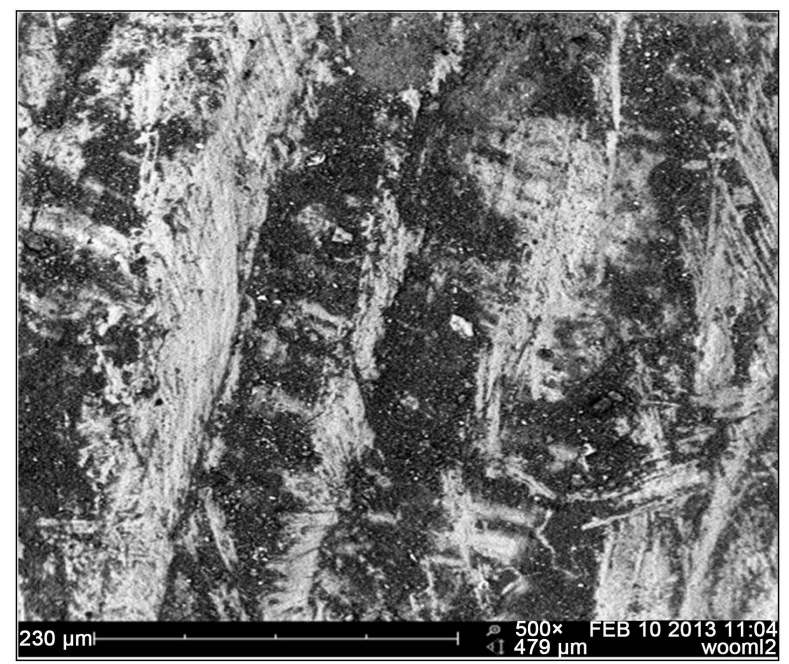

(b)

Figure 10. SEM photomicrographs of worn surfaces of $\mathrm{Al}-6063$ with $5 \% \mathrm{TiB}_{2}$ at $0.5 \mathrm{~m} / \mathrm{s}$ (a) 10 and (b) $30 \mathrm{~N}$.

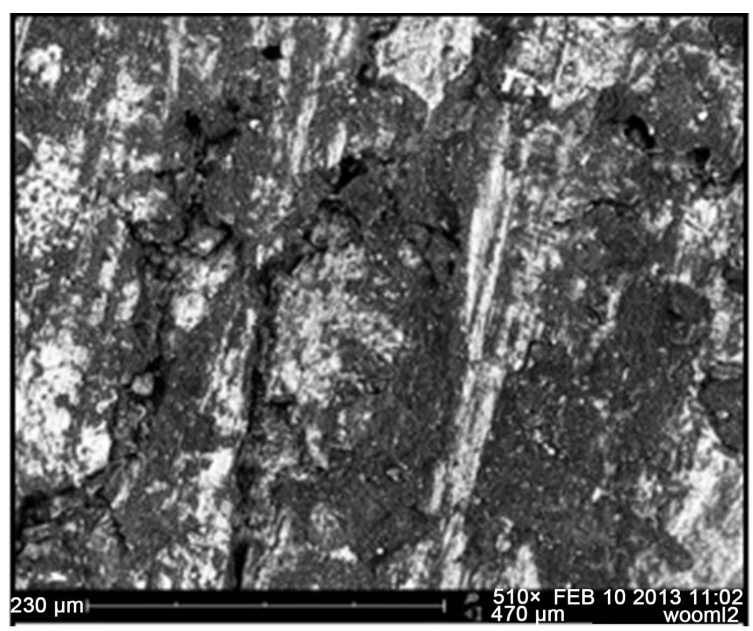

(a)

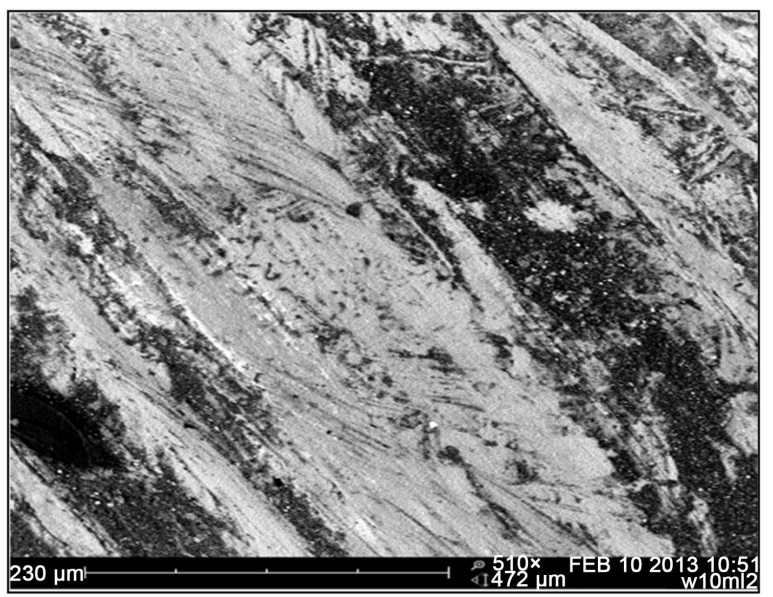

(b)

Figure 11. SEM photomicrographs of worn surfaces of Al-6063 with $5 \% \mathrm{TiB}_{2}$ at $1.5 \mathrm{~m} / \mathrm{s}$ (a) 10 and (b) $30 \mathrm{~N}$. 


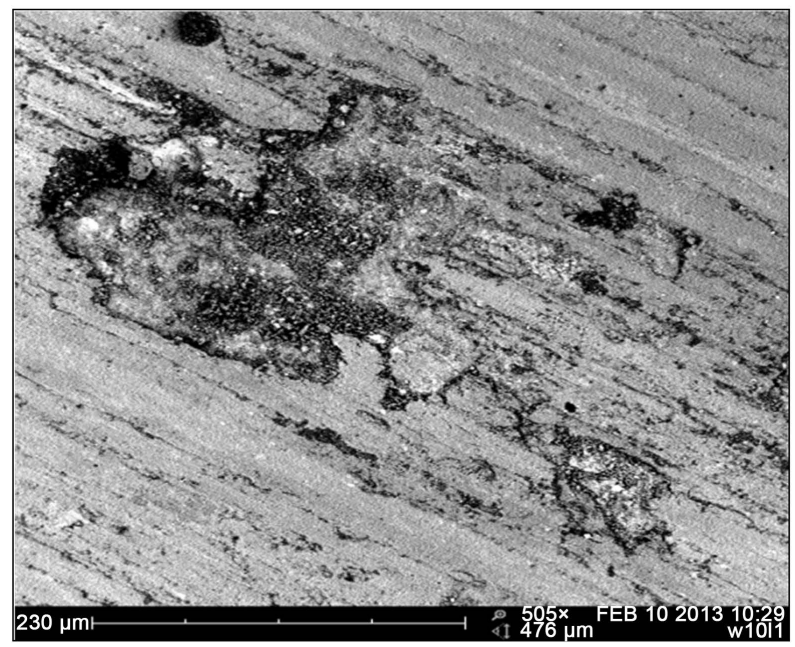

(a)

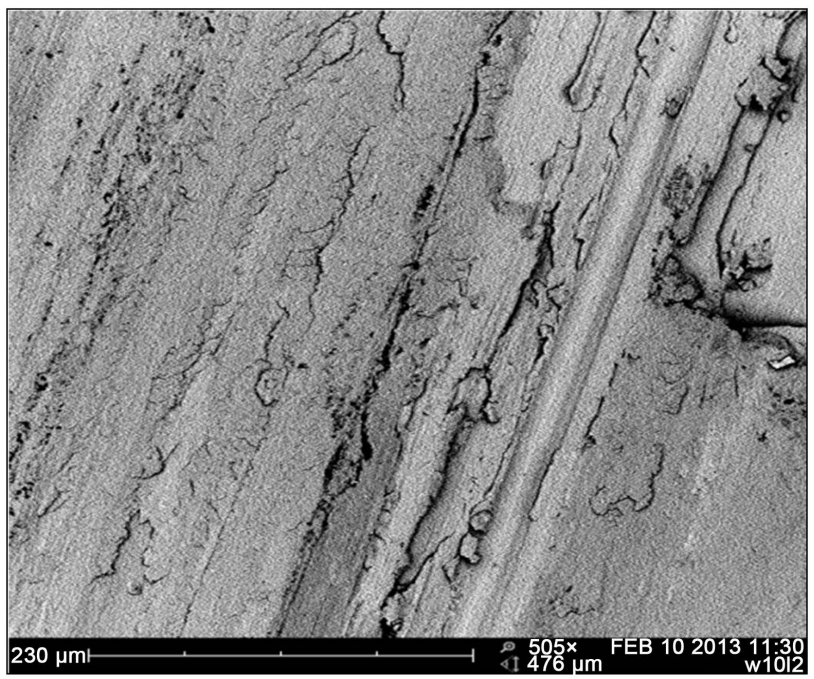

(b)

Figure 12. SEM photomicrographs of worn surfaces of Al-6063 with $10 \% \mathrm{TiB}_{2}$ at $0.5 \mathrm{~m} / \mathrm{s}$ (a) 10 and (b) $30 \mathrm{~N}$.

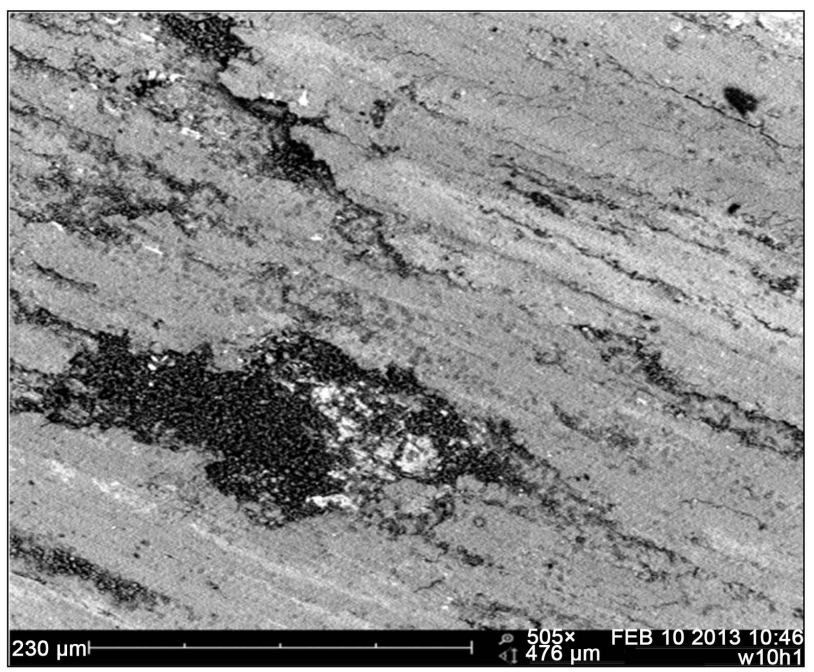

(a) 


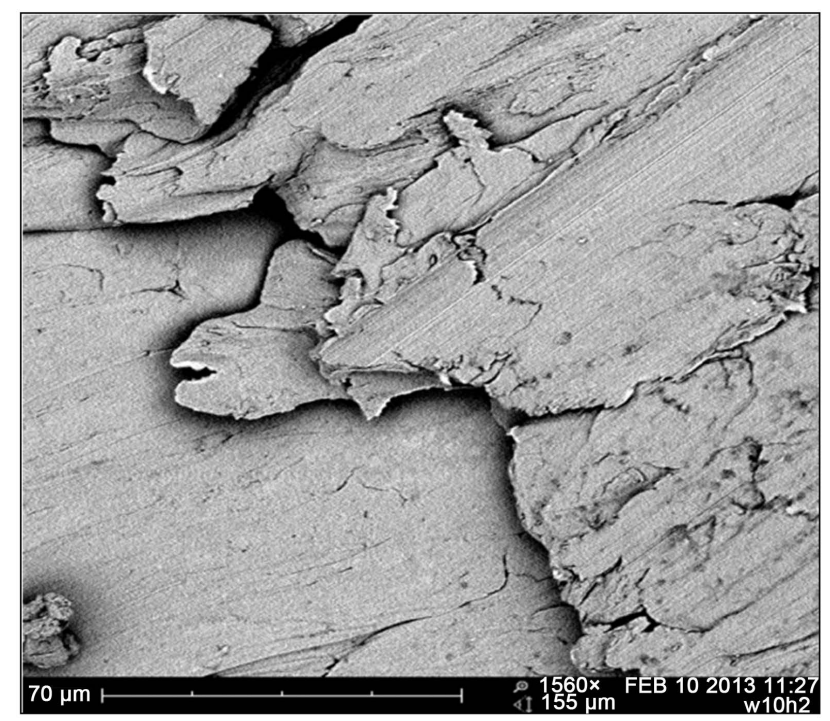

(b)

Figure 13. SEM photomicrographs of worn surfaces of $\mathrm{Al}-6063$ with $10 \% \mathrm{TiB}_{2}$ at $1.5 \mathrm{~m} / \mathrm{s}$ (a) 10 and (b) $30 \mathrm{~N}$.

(Figure 8(b)). At higher sliding velocity i.e., $1.5 \mathrm{~m} / \mathrm{s}$ leads to fisher cracks within the matrix (Figure 9(a)). They are consequential effect of high hardness because of alloying elements such as high silicon, $\mathrm{Cr}$ and $\mathrm{Ti}$ in pure aluminum and are originated from the sliding deformation. Under such conditions, tearing of the larger debris takes place and in the process, the $\mathrm{TiB}_{2}$ particles adhered to the debris are being carried along, leaving behind large craters (Figure $8(\mathrm{~b})$ ). The grooves are deeper in the base alloy as compared to the composites tested under similar conditions ( 10 and $30 \mathrm{~N}$ loads and $0.5 \mathrm{~m} / \mathrm{s}$ and $1.5 \mathrm{~m} / \mathrm{s}$ ), due to the absence of hard $\mathrm{TiB}_{2}$ particle in the base alloy. The wear surface is rough in the base alloy as compared to composites.

The worn surfaces of $\mathrm{TiB}_{2} / \mathrm{Al}-6063$ composites exhibit a feather like structure. This worn surface is associated with plastic flow and adhesion effect, leading to a higher wear loss of composites slid at lower sliding velocity $(0.5 \mathrm{~m} / \mathrm{s})$. However, the worn surface of these composites slid at higher velocity exhibits appearance of both smoother matrix region and rougher white patches. Some surface cracks are also evident from the photomicrographs as shown in Figures 10-13 for 5 and $10 \mathrm{wt} \% \mathrm{TiB}_{2}$ reinforced $\mathrm{Al}$ matrix alloy respectively. According to the well known Archard's law of sliding wear, the volumetric wear loss of the specimen is inversely proportional to its hardness. In present investigation, addition of 10 wt. $\%$ of $\mathrm{TiB}_{2}$ particles reinforced alloy leads to an increase in the hardness value thereby improving its wear resistance significantly. This is also well reflected from the wear data obtained from Figures 4-6 and corroborates the worn surface features of composites.

\section{Conclusions}

Dry sliding wear tests using a pin-on-disc were conducted on $\mathrm{TiB}_{2} / \mathrm{Al}-6063$ composites. The contribution of the reinforcement content and the applied load 
as well as the sliding velocity on the wear process and the wear rate has been investigated. The following conclusions can be drawn from this study: Micro-structural examination showed that the dispersion of $\mathrm{TiB}_{2}$ particles is more or less uniform and lower interface porosity.

1) Hardness of the aluminum alloy improved significantly by adding up of $\mathrm{TiB}_{2}$ particles into Al-6063 alloy, while density of the composite also increased almost linearly with the weight fraction of particles.

2) The effect of the wt\% of reinforcement found to be different for initial wear and the steady-state wear.

3) Sliding wear test results showed that wear rate increases as the increase in the applied load and increase in the sliding velocity. But as the $\mathrm{TiB}_{2}$ reinforcement with the Al-6063 composite increased, the wear rate is decreased with increasing applied load and sliding velocity.

4) The specific wear rate of the composite decreases with the increase in both applied load and the $\mathrm{TiB}_{2}$ particle reinforcement with the Al-6063 composite materials.

5) The wear resistance of Al-6063 alloy is improved by the addition of $\mathrm{TiB}_{2}$ particle and it further increases as the addition $\mathrm{TiB}_{2}$ particle in the composite material increases and it will be maximum for $10 \mathrm{wt} \% \mathrm{TiB}_{2}$.

6) The grooves are deeper in the base matrix alloy due to the absence of $\mathrm{TiB}_{2}$ particle and provide smooth surface compared to composites.

7) Less damage of surface cracks observed in the higher reinforced composite compared to matrix alloy.

8) $10 \mathrm{wt} \% \mathrm{TiB}_{2}$ reinforced Al-6063 composite material posses higher wear resistance and less wear rate, hence it is hard and strong materials compared with matrix and $5 \mathrm{wt} \% \mathrm{TiB}_{2}$ reinforced $\mathrm{Al}-6063$ composite material.

\section{References}

[1] Tjong, S.C. and Lau, K.C. (1999) Sliding Wear of Stainless Steel Matrix Composites Reinforced with $\mathrm{TiB}_{2}$ Particles. Materials Letters, 41, 153-158.

[2] $\mathrm{Xu}$, J. and Liu, W.J. (2006) Wear Characteristic of in situ Synthetic $\mathrm{TiB}_{2}$ Particulate Reinforced Al Matrix Composite Formed by Laser Cladding. Wear, 260, 486-492.

[3] Tjong, S.C., Wu, S.Q. and Zhu, H.G. (1999) Wear Behavior of in situ $\mathrm{TiB}_{2}-\mathrm{Al}_{2} \mathrm{O}_{3} / \mathrm{Al}$ and $\mathrm{TiB}_{2}-\mathrm{Al}_{2} \mathrm{O}_{3} / \mathrm{Al}-\mathrm{Cu}$ Composites. Composites Science and Technology, 59, 13411347.

[4] Tee, K.L., Lu, L. and Lai, M.O. (1999) Synthesis of in situ Al-TiB ${ }_{2}$ Composites Using Stir Cast Route. Composite Structures, 47, 589-593.

[5] Tjong, S.C. and Lau, K.C. (1999) Properties and Abrasive Wear of $\mathrm{TiB}_{2} / \mathrm{Al}-4 \% \mathrm{Cu}$ Composites Produced by Hot Isostatic Pressing. Composite Science \& Technology, 59, 2005-2013.

[6] Tee, K.L., Lu, L. and Lai, M.O. (1999) In situ Processing of Al-TiB2 Composite by the Stir-Casting Technique. Journal of Materials Processing Technology, 89-90, 513-519.

[7] Lu, L., Lai, M.O., Su, Y., Teo, H.L. and Feng, C.F. (2001) In situ $\mathrm{TiB}_{2}$ Reinforced Al Alloy Composites. Scripta Materilia, 45, 1017-1023. 
[8] Mandal, A., Maiti, V., Chakraborty, M. and Murthy, B.S. (2004) Effect of $\mathrm{TiB}_{2}$ Particles on Aging Response of Al-4Cu Alloy. Materials Science and Engineering A, 386, 296-300.

[9] Ramesh, C.S., Ahamed, A., Channabasappa, B.H. and Keshavamurthy, R. (2010) Development of $\mathrm{Al} 6063-\mathrm{TiB}_{2}$ in situ Composites. Materials and Design, 31, 2230 2236.

[10] Mandal, A., Chakraborty, M. and Murthy, B.S. (2007) Effect of $\mathrm{TiB}_{2}$ Particles on Sliding Wear Behavior of Al-4Cu Alloy. Wear, 262, 160-166.

[11] Tee, K.L., Lu, L. and Lai, M.O. (2000) Wear Performance of in situ Al-TiB Compo- $_{2}$ site. Wear, 240, 59-64.

[12] Zhao, M., Wu, G., Jiang, L. and Dou, Z. (2006) Friction and Wear Properties of $\mathrm{TiB}_{2} / \mathrm{Al}$ Composite. Composites Part A, 37, 1916-1921.

[13] Roy, M., Venkataraman, B., Bhanuprasad, V.V., Mahajan, Y.R. and Sunderrajan, G. (1992) The Effect of Particulate Reinforcement on the Sliding Wear Behavior of Aluminium Matrix Composites. Metallurgical and Materials Transactions A, 23, 1916-1921.

[14] Kumar S., Subramanya Sarma, V. and Murthy, B.S. (2007) Influence of in situ Formed $\mathrm{TiB}_{2}$ Particles on the Abrasive Wear Behaviour of Al-4Cu Alloy. Material Science and Engineering A, 465, 160-164.

[15] Kumar, S., Chakraborty, M., Subramanya Sarma, V. and Murthy, B.S. (2008) Tensile and Wear Behaviour of in situ $\mathrm{Al}-7 \mathrm{Si} / \mathrm{TiB}_{2}$ Particulate Composites. Wear, 265 , 134-142.

[16] Ramesh, C.S. and Ahamed, A. (2011) Friction and Wear Behavior of Cast Al 6063 Based in situ Metal Matrix Composites. Wear, 271, 1928-1939.

[17] Sivaprasad, K., Narayanaswamy, R. and Kumaresh Babu, S.P. (2008) Study of Abrasive and Erosive Wear Behavior of $\mathrm{Al} 6063 / \mathrm{TiB}_{2}$ in situ Composites. Materials science and Engineering A, 498, 495-500.

[18] Natarajan, S., Narayanaswamy, R. and Kumaresh Babu, S.P. (2009) Sliding Wear Behavior of $\mathrm{Al} 6063 / \mathrm{TiB}_{2}$ in situ Composites at Elevated Temperature. Materials and Design, 30, 2521-253.

[19] Basavarajappa, S. and Chandramohan, G. (2005) Dry Sliding Wear Behavior of Hybrid Metal Matrix Composites. Materials Science, 11, 253-257.

\section{Submit or recommend next manuscript to SCIRP and we will provide best service for you:}

Accepting pre-submission inquiries through Email, Facebook, LinkedIn, Twitter, etc. A wide selection of journals (inclusive of 9 subjects, more than 200 journals)

Providing 24-hour high-quality service

User-friendly online submission system

Fair and swift peer-review system

Efficient typesetting and proofreading procedure

Display of the result of downloads and visits, as well as the number of cited articles

Maximum dissemination of your research work

Submit your manuscript at: http://papersubmission.scirp.org/

Or contact jmmce@scirp.org 